\title{
Epigallocatechin Gallate
}

National Cancer Institute

\section{Source}

National Cancer Institute. Epigallocatechin Gallate. NCI Thesaurus. Code C1088.

A phenolic antioxidant found in a number of plants such as green and black tea. It inhibits cellular oxidation and prevents free radical damage to cells. It is under study as a potential cancer chemopreventive agent. $(\mathrm{NCl})$ 